\title{
BIOLOGICAL INTEGRITY OF STREAMS IN THE BITTERROOT RIVER TMDL PLANNING AREA BASED ON THE STRUCTURE AND COMPOSITION OF THE BENTHIC ALGAE COMMUNITY
}

\author{
Prepared for: \\ State of Montana \\ Department of Environmental Quality \\ P.O. Box 200901 \\ Helena, Montana 59620-0901 \\ Project Officer: Rosie Sada \\ DEQ Contract No. 200012-8
}

STATE DQEUMENTS COI 1 ECT!

MAY ฉด 2003

MONTANA ST:ATE LIEH

1515 r

Prepared by:

Loren L. Bahls, Ph.D.

Hannaea

1032 Twelfth Avenue

Helena, Montana 59601

May 5, 2003 
○

-

- 


\section{Summary}

In October 2002, periphyton samples were collected from 14 sites on 8 streams in the Bitterroot River TMDL planning area in southwestern Montana for the purpose of assessing whether these streams are water-quality limited and in need of TMDLs. The samples were collected following MDEQ standard operating procedures, processed and analyzed using standard methods for periphyton, and evaluated following modified USEPA rapid bioassessment protocols for wadeable streams.

Diatom metrics indicated moderate impairment from sedimentation and partial support of aquatic life uses at the lower sites on Riemel Creek and Overwhich Creek. Minor impairment from sedimentation was indicated at several sites: Meadow Creek (both sites), Martin Creek (both sites), the upper site on Overwhich Creek, and the upper site on the Nez Perce Fork. The sedimentation index approached but did not exceed the threshold for minor impairment in upper Reimel Creek, Deer Creek, and Buck Creek.

Species of Planothidium were abundant in samples from some of these streams. Diatoms in the genus Planothidium are adapted to living attached to grains of sand. Sandy substrates of decomposed granite are probably common in streams that drain the Idaho Batholith, a region of largely granitic rocks.

The pollution index indicated minor impairment from organic loading at four sites: upper Meadow Creek, Reimel Creek (both sites), and upper Overwhich Creek. The pollution index approached but did not exceed the threshold for minor impairment in lower Meadow Creek and upper Nez Perce Fork. The upper site on Overwhich Creek had the highest saprobity rating: alpha-mesosaprobous/polysaprobous, which indicates an elevated level of organic loading.

An elevated percentage of teratological diatoms indicated possible chronic toxicity from heavy metals in Martin Creek (both sites) and Deer Creek. Deer Creek supported the largest percentage of teratological cells $(1.33 \%)$.

Ditch Creek and the middle and lower sites on the Nez Perce Fork supported large numbers of the diatom Achnanthidium minutissimum, an indicator of disturbance. Large numbers of $A$. minutissimum often indicate natural stresses caused by steep gradients, fast current velocities, cold temperatures, and low nutrient concentrations. Diatoms in Ditch Creek and at the lower two sites on the Nez Perce Fork also demand higher levels of dissolved oxygen than diatoms at other sites, indicating that these sites are better aerated than the others.

The majority of diatoms in streams of the study area are non-motile, alkaliphilous, eutraphentic autotrophs that exert a moderate demand for dissolved oxygen. Most diatoms are in the saprobity class beta-mesosaprobous and indicate fresh-brackish waters. Exceptions include Ditch Creek and the lower sites on the Nez Perce Fork, where most diatoms prefer circumneutral pH and continuously high levels of dissolved oxygen; upper Overwhich Creek, where most diatoms are in saprobity class alpha-mesosaprobous/polysaprobous; lower Overwhich Creek, where oxygen demand is fairly high and trophic status is meso-eutraphentic; and Buck Creek, where oxygen demand is fairly high. 


\section{Introduction}

This report evaluates the biological integrity ${ }^{\prime}$, support of aquatic life uses, and probable causes of stress or impairment to aquatic communities in selected streams of the Bitterroot River TMDL planning area in southwestern Montana. The purpose of this report is to provide information that will help the State of Montana determine whether these streams are waterquality limited and in need of TMDLs.

The federal Clean Water Act directs states to develop water pollution control plans (Total Maximum Daily Loads or TMDLs) that set limits on pollution loading to water-quality limited waters. Water-quality limited waters are lakes and stream segments that do not meet waterquality standards, that is, that do not fully support their beneficial uses. The Clean Water Act and USEPA regulations require each state to (1) identify waters that are water-quality limited, (2) prioritize and target waters for TMDLs, and (3) develop TMDL plans to attain and maintain water-quality standards for all water-quality limited waters.

Evaluation of aquatic life use support in this report is based on the species composition and structure of periphyton (benthic algae, phytobenthos) communities at 14 sites on 8 streams that were sampled in October of 2002. Periphyton is a diverse assortment of simple photosynthetic organisms called algae that live attached to or in close proximity of the stream bottom. Some algae form long filaments or large colonies and are conspicuous to the unaided eye. But most algae, including the ubiquitous diatoms, can be seen and identified only with the aid of a microscope. The periphyton community is a basic biological component of all aquatic ecosystems. Periphyton accounts for much of the primary production and biological diversity in Montana streams (Bahls et al. 1992). Plafkin et al. (1989) and Barbour et al. (1999) list several advantages of using periphyton in biological assessments.

\footnotetext{
${ }^{1}$ Biological integrity is defined as "the ability of an aquatic ecosystem to support and maintain a balanced, integrated, adaptive community of organisms having a species composition, diversity, and functional organization comparable to that of natural habitats within a region" (Karr and Dudley 1981).
} 


\section{Project Area and Sampling Sites}

The project area is located within the Montana extension of the Idaho Batholith Ecoregion in Ravalli County, Montana. This ecoregion is mountainous, deeply dissected, partially glaciated, and characteristically underlain by granitic rocks. Soils derived from granitics are droughty and have limited fertility, and therefore provide only limited amounts of nutrients to aquatic systems (McGrath et al. 2001). Vegetation in the project area is mixed conifer forest at higher elevations and ponderosa pine, shrubs and grasses at lower elevations (USDA 1976, Woods et al. 1999). The main land uses are logging, grazing, recreation, mining, and wildlife production. Streams in this ecoregion are likely to suffer from increased loads of fine sediments after disturbance by humans. In the Idaho portion of this ecoregion, logging has caused slope instability (especially in granitic areas) and stream sedimentation. Placer gold mining has heavily affected rivers in this ecoregion in the state of Idaho (McGrath et al. 2001).

Periphyton samples were collected at 14 sites on 8 streams (Table 1). The study streams are headwater tributaries of the Bitterroot River in USGS hydrologic unit 17010205. The Bitterroot River is a tributary of the Clark Fork River. Streams in the project area are classified B-1 in the Montana Surface Water Quality Standards.

\section{Methods}

Periphyton samples were collected following standard operating procedures of the MDEQ Planning, Prevention, and Assistance Division. Using appropriate tools, microalgae were scraped, brushed, or sucked from natural substrates in proportion to the importance of those substrates at each study site. Macroalgae were picked by hand in proportion to their abundance at the site. All collections of microalgae and macroalgae were pooled into a common container and preserved with Lugol's (IKI) solution.

The samples were examined to estimate the relative abundance and rank by biovolume of diatoms and genera of soft (non-diatom) algae according to the method described in Bahls (1993). Soft algae were identified using Smith (1950), Prescott (1962, 1978), John et al. (2002), 
and Wehr and Sheath (2003). These books also served as references on the ecology of the soft algae, along with Palmer $(1969,1977)$.

After the identification of soft algae, the raw periphyton samples were cleaned of organic matter using sulfuric acid, potassium dichromate, and hydrogen peroxide. Then permanent diatom slides were prepared using Naphrax, a high refractive index mounting medium, following Standard Methods for the Examination of Water and Wastewater (APHA 1998). At least 400 diatom cells ( 800 valves) were counted at random and identified to species. The following were the main taxonomic references for the diatoms: Krammer and Lange-Bertalot 1986, 1988, 1991 a, 1991 b; Lange-Bertalot 1993, 2001; Krammer 1997a, 1997b, 2002; Reichardt 1997, 1999. Diatom naming conventions followed those adopted by the Academy of Natural Sciences for USGS NAWQA samples (Morales and Potapova 2000) as updated in 2003 (Dr. Eduardo Morales, Academy of Natural Sciences, digital communication). Van Dam et al. (1994) was the main ecological reference for the diatoms.

The diatom proportional counts were used to generate an array of diatom association metrics. A metric is a characteristic of the biota that changes in some predictable way with increased human influence (Barbour et al. 1999). Diatoms are particularly useful in generating metrics because there is a wealth of information available in the literature regarding the pollution tolerances and water quality preferences of common diatom species (e.g., Lowe 1974, Beaver 1981, Lange-Bertalot 1996, Van Dam et al. 1994).

Values for selected metrics were compared to biocriteria (numeric thresholds) developed for streams in the Rocky Mountain ecoregions of Montana (Table 2). These criteria are based on metric values measured in least-impaired reference streams (Bahls et al. 1992) and metric values measured in streams that are known to be impaired by various sources and causes of pollution (Bahls 1993). The biocriteria in Table 2 are valid only for samples collected during the summer field season (June 21-September 21).

The criteria in Table 2 distinguish among four levels of stress or impairment and three levels of aquatic life use support: (1) no impairment or only minor impairment (full support), 
(2) moderate impairment (partial support), and (3) severe impairment (nonsupport). These impairment levels correspond to excellent, good, fair, and poor biological integrity, respectively. In cold, high-gradient mountain streams, natural stressors will often mimic the effects of mancaused impairment on some metric values.

\section{Quality Assurance}

Several steps were taken to assure that the study results are accurate and reproducible.

Upon receipt of the samples, station and sample attribute data were recorded in the Montana Diatom Database and the samples were assigned a unique number, e.g., 2639-01. The first part of this number (2639) designates the sampling site (Meadow Creek above Spruce Creek) and the second part (01) designates the number of periphyton samples that that have been collected at this site for which data have been entered into the Montana Diatom Database.

Sample observations and analyses of soft (non-diatom) algae were recorded in a lab notebook along with information on the sample label. A portion of the raw sample was used to make duplicate diatom slides. The slide used for the diatom proportional count will be deposited in the Montana Diatom Collection at the University of Montana Herbarium in Missoula. The duplicate slide will be retained by Hannaea in Helena. Diatom proportional counts have been entered into the Montana Diatom Database.

\section{Results and Discussion}

Results are presented in Tables 3, 4 and 5, which are located near the end of this report following the references section. Copies of aquatic plant field sheets are included as Appendix A. Appendix B contains a series of diatom reports, one for each sample. Each diatom report contains an alphabetical list of diatom species in that sample and their percent abundances, and values for 65 different diatom metrics and ecological attributes. 


\section{Sample Notes}

Meadow Creek. The samples from Meadow Creek contained mostly moss. The sample from the upper site was silty and the sample from the lower site was very silty.

Martin Creek. Both samples from Martin Creek consisted mostly of moss. The sample from the lower site was silty, but silt was not conspicuous in the sample from the upper site.

Reimel Creek. Samples from both sites on Reimel Creek were silty. The sample from the upper site contained moss.

Ditch Creek. The sample from Ditch Creek was sparse and only an occasional diatom was observed during the scan of soft algae.

Deer Creek. Large cohesive mats of Oscillatoria sp. were abundant in the sample from Deer Creek. Large, ear-shaped colonies of Nostoc sp. were also frequent in this sample.

Overwhich Creek. Mats of Oscillatoria sp. dominated the sample from the upper site. Filaments of Oscillatoria sp. dominated the sample from lower Overwhich Creek and colonies of Nostoc sp. (round and ear-shaped) were frequent here.

Buck Creek. The sample from Buck Creek contained moss and filaments of Vaucheria sp. were observed tangled in the moss.

Nez Perce Fork. The sample from the upper site contained mostly moss. Two large ear-shaped colonies of Nostoc sp. were also found in this sample. The Chamaesiphon sp. in this sample occurred as an epiphyte on Audouinella violacea. Stalks and cells of Didymosphenia sp. dominated the sample from the middle site on Nez Perce Fork, whereas Rhopalodia gibba was the visually most conspicuous diatom in the sample from the lower site. 


\section{Non-Diatom Algae (Table 3)}

Meadow Creek. Diatoms were the only common algae in the sample from Meadow Creek. Other algae included a few genera of green algae and cyanobacteria.

Martin Creek. Diatoms ranked first in biovolume in both samples from Martin Creek. In addition to diatoms, the desmid Closterium and the filamentous cyanophyte Tolypothrix were common at the upper site. Tolpothrix prefers unpolluted fresh waters. At the lower site, the most common non-diatom algae were Microspora sp., a filamentous green, and Nostoc sp., a colonial cyanophyte. Microspora prefers cool waters and some species are frequent in low $\mathrm{pH}$ environments. Tolypothrix and Nostoc are both nitrogen fixers and indicate that nitrogen is probably the limiting nutrient in Martin Creek.

Reimel Creek. The sample from upper Reimel Creek contained only diatoms and an occasional cell of Microspora. Diatoms dominated the sample from lower Reimel Creek, where the cyanophyte Oscillatoria was frequent and ranked second and the chrysophyte Hydrurus foetidus was common and ranked third in biovolume. Hydrurus foetidus is a cold-water stenotherm that is common in mountain streams. It requires water temperatures below $10^{\circ} \mathrm{C}$ and prefers bright sunlight and waters of relatively low $\mathrm{pH}$.

Ditch Creek. Cells of Tolypothrix were frequent and this nitrogen-fixing cyanophyte ranked first in biovolume in the sample from Ditch Creek. Other filamentous cyanobacteria were also found here, including the nitrogen-fixing genus Nodularia. Diatoms were sparse in the sample from Ditch Creek.

Deer Creek. The cyanophyte Oscillatoria was abundant and ranked first in biovolume in Deer Creek. Oscillatoria is a large genus and species from this genus are found in a wide range of habitats. Some species of Oscillatoria are tolerant of pollution and when abundant they may indicate nutrient enrichment and eutrophic conditions. The nitrogen-fixing cyanophyte Nostoc ranked sccond in the sample from Deer Creek. Nostoc parmelioides, the species found in Deer Creek, grows on stones in mountain streams. It normally produces spherical colonies, but 
produces ear-shaped colonies after being occupied by aquatic midge larvae. The filamentous green alga Zygnema was frequent and ranked third in biovolume in the Deer Creek sample. Zygnema is widespread and prefers neutral to slightly acidic waters.

Overwhich Creek. Besides diatoms, which were abundant in both samples, Oscillatoria dominated the periphyton community at both sites on Overwhich Creek. (See discussion of Oscillatoria under Deer Creek.) The green alga Gongrosira was frequent and ranked third in biovolume at the upper site. Gongrosira forms crusts on hard surfaces and prefers alkaline waters. The nitrogen-fixer Nostoc was frequent and ranked third at the lower site. The attached filamentous green alga Ulothrix was conmon and ranked fourth at both sites. Ulothrix grows attached to rocks in streams with slow to moderate currents and generally prefers cool waters.

Buck Creek. The coenocytic filamentous Valcheria (Tribophyceae) was abundant and ranked first in biovolume in the sample from Buck Creek. Vaucheria typically grows on muddy bottoms and prefers cool waters of low to medium nutrient content. It is sensitive to desiccation so its presence is usually an indicator of constant flows and the absence of dewatering. Other algae, including diatoms, were rare to occasional in the sample from Buck Creek.

Nez Perce Fork. Diatoms were most abundant and ranked first in biovolume in samples from the upper and middle sites on Nez Perce Fork. Nostoc was frequent and ranked second at the upper site, followed by the desmid Closterium (common) and the xanthophyte Tribonema (occasional). Closterium includes many widespread species that are found in a wide variety of habitats. The ecology of Tribonema is similar to that of Vaucheria in that it prefers cool waters of low to medium nutrient content.

At the middle site, the second-, third- and fourth-ranked genera were Oscillatoria, Audouinella, and Spirogyra, respectively. Audouinella is a filamentous red alga. Audouinella hermainnii, the most common species in North America, prefers $\operatorname{cool}\left(\sim 11^{\circ} \mathrm{C}\right)$, mildly alkaline $(\mathrm{pH} \sim 7.5)$ waters of low ionic content $(\sim 100 \mathrm{uS})$. 
Spirogyra ("pond scum") was the dominant alga at the lower site on Nez Perce Fork, perhaps indicating slower current velocities, warmer water temperatures and higher nutrient concentrations than the upper sites. Zygnema, another filamentous green, ranked second at the lower site and diatoms ranked third. Zygnema is widespread and prefers neutral to slightly acidic waters. Audouinella was common and ranked fourth at the lower site.

\section{Diatoms (Table 4)}

All but one of the major diatom species from the Bitterroot River TMDL planning area are included in pollution tolerance classes 3 and 2 , and are either sensitive to organic pollution or only somewhat tolerant of organic pollution (Table 4). The one exception was Gomphonema parvulum, which is most tolerant of organic pollution (pollution tolerance class $=1$ ). Gomphonema parnulum was a major species ( $>5 \%$ relative abundance) only in Ditch Creek, which demonstrated good biological integrity except for minor natural stresses (see below).

Stresses indicated at some of the sites appear to be natural in origin. For example, high values for the disturbance index and percent dominant species in Ditch Creek and the middle and lower sites on the Nez Perce Fork (Table 4) indicate minor stress related to steep gradients, fast currents, cold temperatures, and low nutrient concentrations. High values for the pollution index and low values for the siltation index and percent abnormal cells indicate that organic enrichment, sedimentation, and toxic metals did not have a significant effect on the benthic algae at these sites. These three sites also had the highest ratings for dissolved oxygen (continuously high), indicating that they had the steepest gradients and highest saturation of dissolved oxygen (Table 5).

Meadow Creek. Both sites on Meadow Creek supported an elevated percentage of motile diatoms (Navicula and Nitzschia), which indicated minor impairment from sedimentation (Table 4). The siltation index was larger at the upstream site than at the downstream site. The dominant diatom species at the upstream site was Planothidium lanceolatum, a specialized species adapted to living attached to sand grains. This species was also common at the downstream site. The pollution index indicated minor impairment from organic loading at the 
upstream site. The pollution index value at the downstream site was close to the threshold for minor impairment. Like Planothidium lanceolatum at the upstream site, the dominant species at the downstream site-Encyonema silesiacum - is somewhat tolerant of organic loading. The two sites on Meadow Creek shared about half of their diatom floras, indicating that only a small amount of floristic and environmental change occurred between them.

Martin Creek. Elevated siltation index values indicated minor impairment from sedimentation at both sites on Martin Creek. Both sites also supported a few teratological valves, indicating possible chronic toxicity from heavy metals or some other stressor. The pollution index was acceptably high at both sites, indicating little organic loading. The dominant species at both sites was Cocconeis placentula, a species adapted to living on rocks and other hard surfaces. The two sites shared almost three-quarters of their diatom assemblages, which indicate virtually no floristic or ecological difference existed between them.

Reimel Creek. Both sites on Reimel Creek supported an elevated number of pollutiontolerant diatoms for a mountain stream, indicating minor impairment from organic loading. Such common pollution-tolerant species as Nitzschia archibaldii, Planothidium dubium, Planothidium lanceolatum, and Synedra ulna were common in Reimel Creek. The siltation index at the downstream site exceeded the threshold for moderate impairment and partial support of aquatic life uses. At the upstream site, the siltation index approached but did not exceed the threshold for minor impairment. However, the large number of diatoms in the genus Planothidium at the upstream site indicated a sandy substrate here. The two sites on Reimel Creek shared less than half of their diatom associations, indicating minor to moderate change occurred between them.

Ditch Creek. Other than an elevated number of Achnanthidium minutissimum, diatom metrics indicated excellent biological integrity and full support of aquatic life uses in Ditch Creek. The stress registered here is probably natural in origin and related to steep gradients, fast current velocities, cold temperatures, and low nutrient concentrations. 
Deer Creek. The only indication of stress in Deer Creek was an elevated number of teratological diatom valves in the species Synedra ulna. This may indicate chronic toxicity from heavy metals or some other stressor. The percentage of motile diatoms approached but did not exceed the threshold for minor impairment from sedimentation. Otherwise, diatom metrics indicated excellent biological integrity and full support of aquatic life uses in Deer Creek.

Overwhich Creek. Diatom metrics indicated minor impairment from organic loading and sedimentation at the upper site on Overwhich Creek. The dominant species here was Synedra ulna, which is somewhat tolerant of organic loading. At the downstream site, the percentage of motile diatoms exceeded the threshold for moderate impairment from sedimentation. The dominant diatom here was Nitzschia dissipata, a highly motile and eutraphentic species. The two sites on Ovenwhich Creek shared slightly less than half of their diatom assemblages, indicating that minor to moderate change occurred between them.

Buck Creek. The only indication of stress at this site was an elevated number of diatoms in the species Meridion circulare. This is a pollution sensitive species that prefers cool water temperatures and constant flows. Being neither attached nor motile, $M$. circulare cannot withstand high current velocities or large amounts of sediment (bedload). Nevertheless, the sedimentation index in Buck Creek approached but did not exceed the criterion for minor impairment. In other respects, Buck Creek demonstrated excellent biological integrity and no impairment of aquatic life uses.

Nez Perce Fork. The upper site on the Nez Perce Fork of the Bitterroot River had the lowest pollution index and the highest sedimentation index of the three sites. The pollution index approached but did not exceed the threshold for minor impairment, but the sedimentation index did indicate minor impairment. The dominant diatom here was Planothidium lanceolatum, a species adapted to living on sand grains. The abundance of Planothidium species here and at other sites in the study area may reflect an adaptation to sandy substrates of decomposed granite that is typical of these streams. Nitzschia dissipata-a highly motile and eutraphentic speciesranked second in abundance at the upper site on the Nez Perce Fork. 
An elevated number of Achnanthidium minutissimum indicated minor stress at the two downstream sites on the Nez Perce Fork. This stress is probably natural in origin and caused by steep gradients, fast current velocities, cold temperatures, and low nutrient concentrations. Otherwise, diatom metrics indicated excellent biological integrity and full support of aquatic life uses at both of the downstream sites.

The upstream and middle sites on Nez Perce Fork shared less than 20 percent of their diatom assemblages, indicating that major floristic and environmental changes occurred between the two sites. On the other hand, the two downstream sites were very similar, floristically, indicating virtually no change occurred between them.

\section{Modal Categories of Ecological Attributes (Table 5)}

Several ecological attributes assigned by Stevenson and Van Dam et al. (1994) were selected from the diatom reports in the appendix and modal categories of these attributes were extracted to characterize water quality tendencies in streams of the Bitterroot River TMDL planning area (Table 5). With few exceptions, most of the diatoms that inhabit these streams may be characterized as non-motile, alkaliphilous, and autotrophic, while tolerating high levels of organic nitrogen. They prefer eutrophic, fresh-brackish waters, and exert a moderate demand for dissolved oxygen. These categories are defined by Van Dam et al. (1994)

A few sites exhibit significant departures from these trends. For example, most diatoms in Ditch Creek and at the middle and lower sites on Nez Perce Fork prefer circumneutral (rather than alkaline) waters and exert a continuously high (rather than moderate) demand for dissolved oxygen. The modal category for saprobity at the upper site on Overwhich Creek is alphamesosaprobous/polysaprobous, which indicates a higher level of organic loading than at most of the other sites in the study area. At the lower site on Overwhich Creek, the modal category for dissolved oxygen is "fairly high" and the modal category for trophic state is meso-eutraphentic, which indicate better oxygenated waters and lower nutrient concentrations than at most of the other sites. The modal category for dissolved oxygen in Buck Creek is also "fairly high", in contrast to "moderate" at most of the other sites. 


\section{References}

APHA. 1998. Standard Methods for the Examination of Water and Wastewater. $20^{\text {th }}$ Edition. American Public Health Association, Washington, D.C.

Bahls, L.L. 1979. Benthic diatom diversity as a measure of water quality. Proceedings of the Montana Academy of Sciences 38:1-6.

Bahls, L.L. 1993. Periphyton Bioassessment Methods for Montana Streams (revised). Montana Department of Health and Environmental Sciences, Helena.

Bahls, L.L., Bob Bukantis, and Steve Tralles. 1992. Benchmark Biology of Montana Reference Streams. Montana Department of Health and Enviroumental Sciences, Helena.

Barbour, M.T., J. Gerritsen, B.D. Snyder, and J.B. Stribling. 1999. Rapid Bioassessment Protocols for Use In Streams and Wadeable Rivers: Periphyton, Benthic Macroinvertebrates and Fish. Second Edition. EPA/84 1-B-99-002. U.S. Environmental Protection Agency, Office of Water, Washington, D.C.

Beaver, Janet. 1981. Apparent Ecological Characteristics of Some Common Freshwater Diatoms. Ontario Ministry of The Environment, Technical Support Section, Don Mills, Ontario.

Johansen, J.R. 1999. Diatoms of Aerial Habitats. Chapter 12 in Stoermer, E.F., and J.P. Smol (eds.), The Diatoms: Applications For the Environmental and Earth Sciences, Cambridge University Press, New York.

John, D.M., B.A. Whitton, and A.J. Brook (eds.). 2002. The Freshwater Algal Flora of the British Isles: An Identification Guide to Freshwater and Terrestrial Algae. Cambridge University

Karr, J.R., and D.R. Dudley. 1981. Ecological perspectives on water quality goals. Environmental Management 5:55-69.

Krammer, Kurt. 1997a. Die cymbelloiden Diatomeen: Eine Monographie der weltweit bekannten Taxa. Teil 1. Allgemeines and Encyonema Part. J. Cramer, Berlin.

Krammer, Kurt. 1997b. Die cymbelloiden Diatomeen: Eine Monographie der weltweit bekannten Taxa. Teil 2. Encyonema part., Encyonopsis and Cymbellopsis. J. Cramer, Berlin.

Krammer, Kurt. 2002. Cymbella. Volume 3 in Diatoms of Europe, Horst Lange-Bertalot, ed. A.R.G. Gantner Verlag K.G., Germany.

Krammer, K., and H. Lange-Bertalot. 1986. Bacillariophyceae, Part 2, Volume 1: Naviculaceae. In Ettl, H., J Gerloff, H. Heynig, and D. Mollenhauer (eds.), Freshwater Flora of Middle Europe. Gustav Fischer Publisher, New York.

Krammer, K., and H. Lange-Bertalot. 1988. Bacillariophyceae, Part 2, Volume 2: Bacillariaceae, Epithemiaceae, Surirellaceae. In Ettl, H., J. Gerloff, H. Heynig, and D. Mollenhauer (eds.), Freshwater Flora of Middle Europe. Gustav Fischer Publisher, New York.

Krammer, K., and H. Lange-Bertalot. 1991a. Bacillariophyceae, Part 2, Volume 3: Centrales, Fragilariaceae, Eunotiaceae. In Ettl, H., J. Gerloff, H. Heynig, and D. Mollenhauer (eds.), Freshwater Flora of Middle Europe. Gustav Fischer Publisher, Stuttgart.

Krammer, K., and H. Lange-Bertalot. 1991b. Bacillariophyceae, Part 2, Volume 4: Achnanthaceae, Critical Supplement to Navicula (Lineolatae) and Gomphonema, Complete List of Literature for Volumes 1-4. In Ettl, H., G. Gartner, J. Gerloff, H. Heynig, and D. Mollenhauer (eds.), Freshwater Flora of Middle Europe. Gustav Fischer Publisher, Stuttgart. 
Lange-Bertalot, Horst. 1979. Pollution tolerance of diatoms as a criterion for water quality estimation. Nova Hedwigia 64:285-304.

Lange-Bertalot, Horst. 1993. 85 new taxa and much more than 100 taxonomic clarifications supplementary to Susswasserflora von Mitteleuropa Vol. 2/1-4. J. Cramer, Berlin.

Lange-Bertalot, Horst. 1996. Rote Liste der limnischen Kieselalgen (Bacillariophyceae) Deutschlands. Schr.-R. f. Vegetationskde., H. 28, pp. 633-677. BN, Bonn-Bad Godesberg.

Lange-Bertalot, Horst. 2001. Novicula sensu stricto: 10 Genera Separated from Navicula sensu lato; Frustulia. Volume 2 in Diatoms of Europe, Horst Lange-Bertalot, ed. A.R.G. Gantner Verlag K.G., Germany.

Lowe, R.L. 1974. Environmental Requirements and Pollution Tolerance of Freshwater Diatoms. EPA-670/4-74-005. U.S. Environmental Protection Agency, National Environmental Research Center, Office of Research and Development, Cincinnati, Ohio.

McFarland, B.H., B.H. Hill, and W.T. Willingham. 1997. Abnormal Fragilaria spp. (Bacillariophyceae) ln streams impacted by mine drainage. Journal of Freshwater Ecology 12(1):141-149.

McGrath, C.L., A.J. Woods, J.M. Omernik, S.A. Bryce, M. Edmondson, J.A. Nesser, J. Shelden, R.C. Crawford, J.A. Comstock, and M.D. Plocher. 2001. Ecoregions of Idaho (color poster with map, descriptive text, summary tables, and photographs). U.S. Geological Sur'ey, Reston, Virginia.

Morales, E.A., and Marina Potapova. 2000. Third NAWQA Workshop on Harmonization of Algal Taxonomy, May 2000. Patrick Center for Environmental Research, The Academy of Natural Sciences, Philadelphia.

Palmer, C.M. 1969. A composite rating of algae tolerating organic pollution. Journal of Phycology 5:78-82.

Palmer, C.M. 1977. Algae and Water Pollution: An Illustrated Manual on the Identification, Significance, and Control of Algae in Water Supplies and in Polluted Water. EPA-600/9-77-036.

Plafkin, J.L., M.T. Barbour, K.D. Porter, S.K. Gross, and R.M. Hughes. 1989. Rapid Bioassessment Protocols for Use in Rivers and Streams: Benthic Macroinvertebrates and Fish. EPA 440-4-89-001.

Prescott, G.W. 1962. Algae of the Western Great Lakes Area. Wm. C. Brown Company, Dubuque, lowa.

Prescott, G.W. 1978. How to Know the Freshwater Algae. Third Edition. Wm. C. Brown Company Publishers, Dubuque, Iowa.

Reichardt, Erwin. 1997. Taxonomische Revision des Artenkomplexes um Gomphonema pumilum (Bacillariophyta). Nova Hedwigia 65(1-4):99-129.

Reichardt, Erwin. 1999. Zur Revision der Gattung Gomphonema. A.R.G. Gantner Verlag, Distributed by Koeltz Scientific Books, Konigstein, Germany.

Renfro, H.B., and D.E. Feray. 1972. Geological Highway Map of the Northern Rocky Mountain Region. American Association of Petroleum Geologists, Tulsa, Oklahoma.

Smith, G.M. 1950. The Fresh-Water Algae of The United States. McGraw-Hill Book Company, New York.

Stevenson, R.J., and Y. Pan. 1999. Assessing Environmental Conditions in Rivers and Streams with Diatoms. Chapter 2 in Stoermer, E.F., and J.P. Smol (eds.), The Diatoms: Applications For the Environmental and Earth Sciences, Cambridge University Press, New York. 
Stewart, W.D.P., P. Rowell, and A.N. Rai. 1980. Symbiotic Nitrogen-Fixing Cyanobacteria. Pp. 239-277 in Stewart, W.D.P., and J. Gallo (eds.), Nitrogen Fixation, Academic Press, New York.

USDA. 1976. Climax Vegetation of Montana (map). U.S. Department of Agriculture, Soil Conservation Service, Cartographic Unit, Portland.

USEPA. 2000. Level 111 Ecoregions of the Continental United States (map). National Health and Environmental Effects Research Laboratory, U.S. Environmental Protection Agency, Corvallis, Oregon.

Van Dam, Herman, Adrienne Mertens, and Jos Sinkeldam. 1994. A coded checklist and ecological Indicator values of freshwater diatoms from The Netherlands. Netherlands Journal of Aquatic Ecology 28(1):117-133.

Weber, C.1. (ed.). 1973. Biological Field and Laboratory Methods for Measuring the Quality of Surface Waters and Effluents. EPA-670/4-73-001. U.S. Environmental Protection Agency, National Environmental Research Center, Office of Research and Development, Cincinnati, Ohio.

Wehr, J.D., and R.G. Sheath. 2003. Freshwater Algae of North America: Ecology and Classification. Academic Press, New York.

Whittaker, R.H. 1952. A study of summer foliage insect communities in the Great Smoky Mountains. Ecological Monographs 22:1-44.

Woods, A.J., Omernik, J.M., Nesser, J.A., Shelden, J., and S.H. Azevedo. 1999. Ecoregions of Montana (color poster with map), U.S. Geological Survey, Reston, Virginia. 


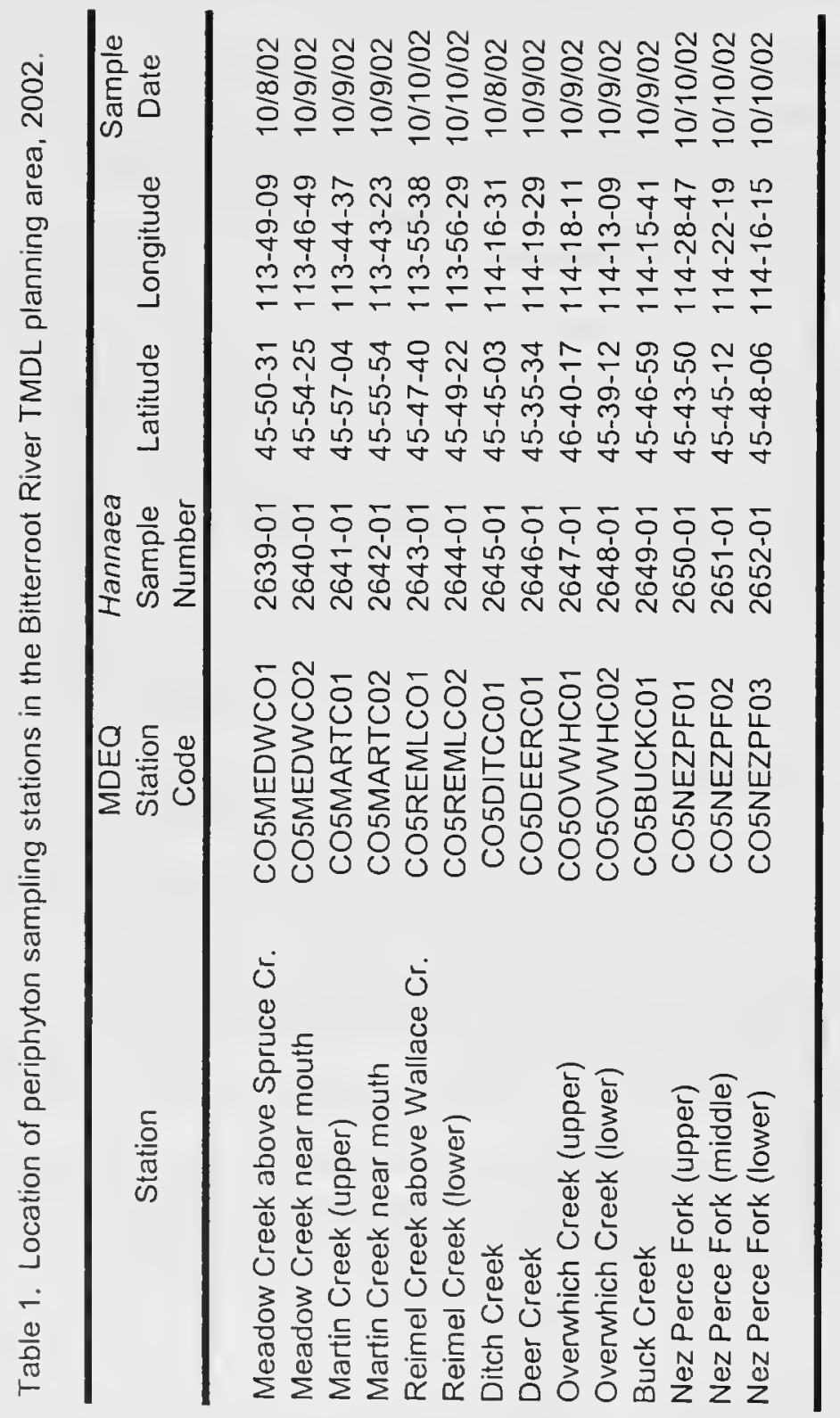




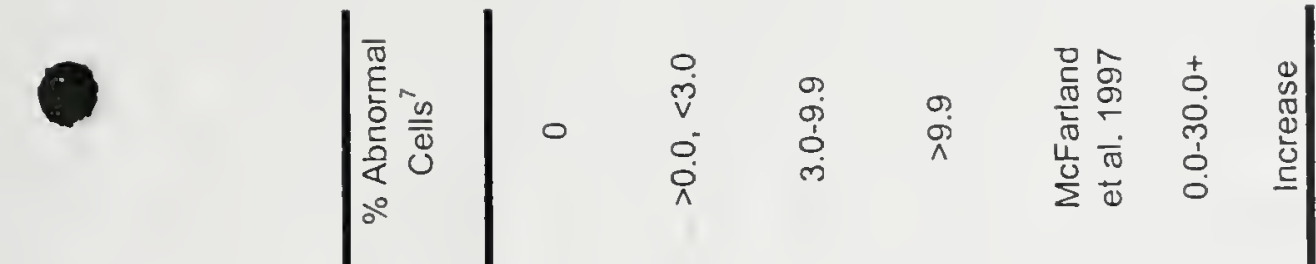

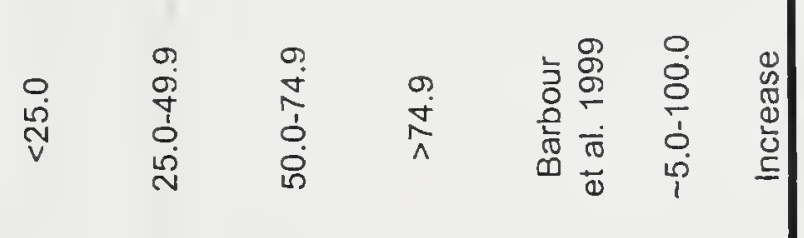

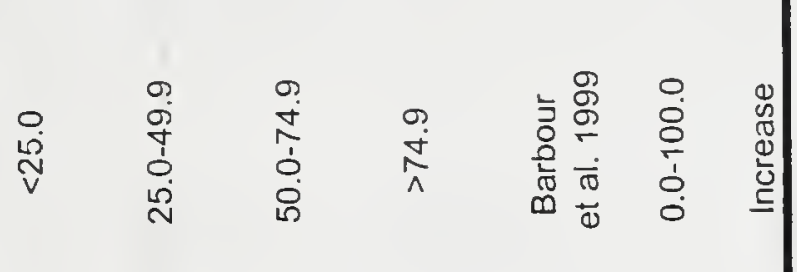

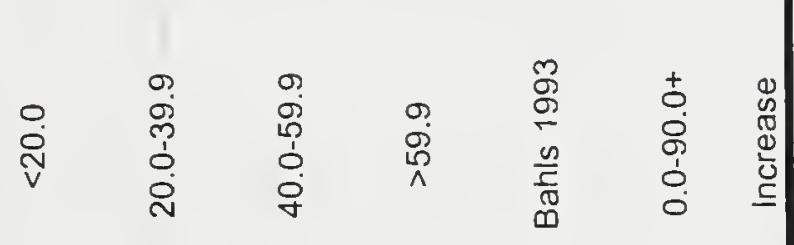

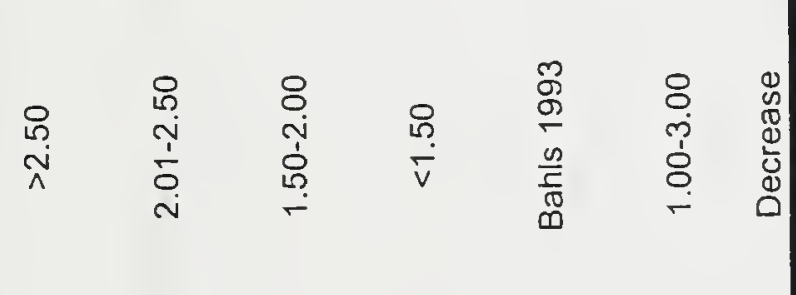

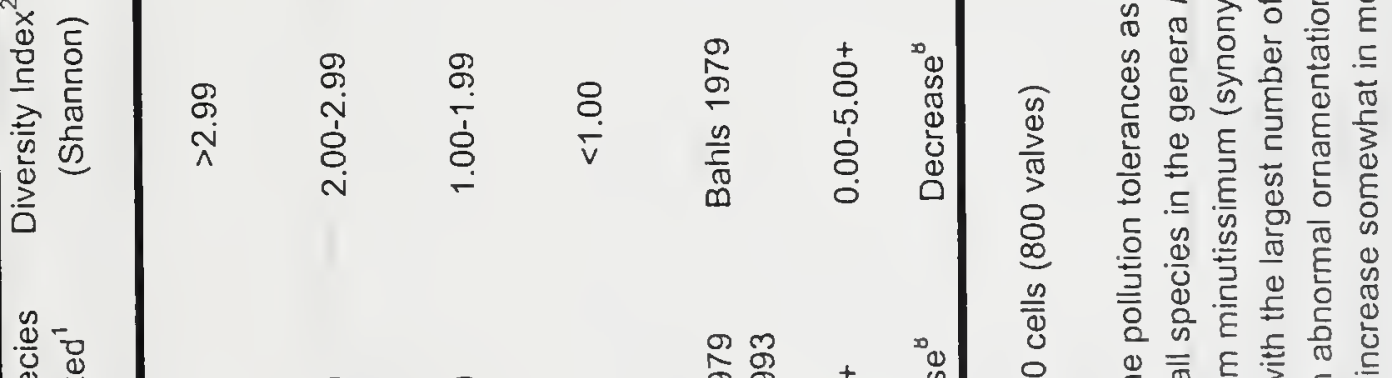

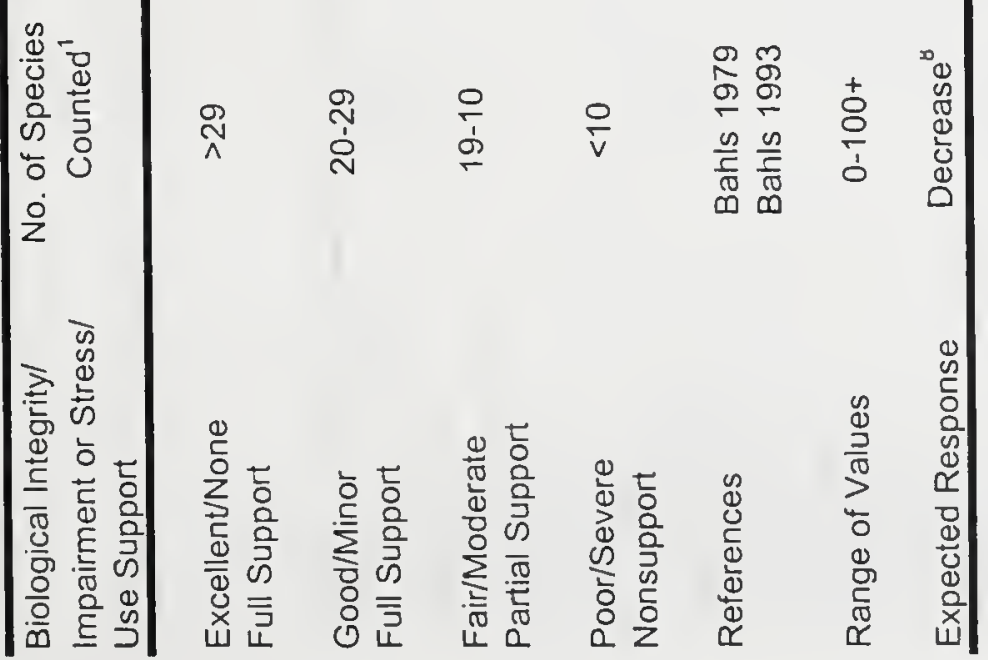

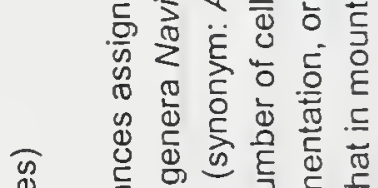

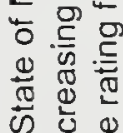

$$
\begin{aligned}
& \text { 里 } \\
& \text { 도응 }
\end{aligned}
$$

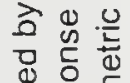

$$
\begin{aligned}
& \text { की } \\
& \text { 记 } \\
& \text { 迹 } \\
& \text { 든 } \\
& \text { is } \\
& \text { ช }
\end{aligned}
$$

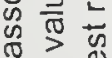

$$
\begin{aligned}
& \text { ह 잉 } \\
& \text { - }
\end{aligned}
$$

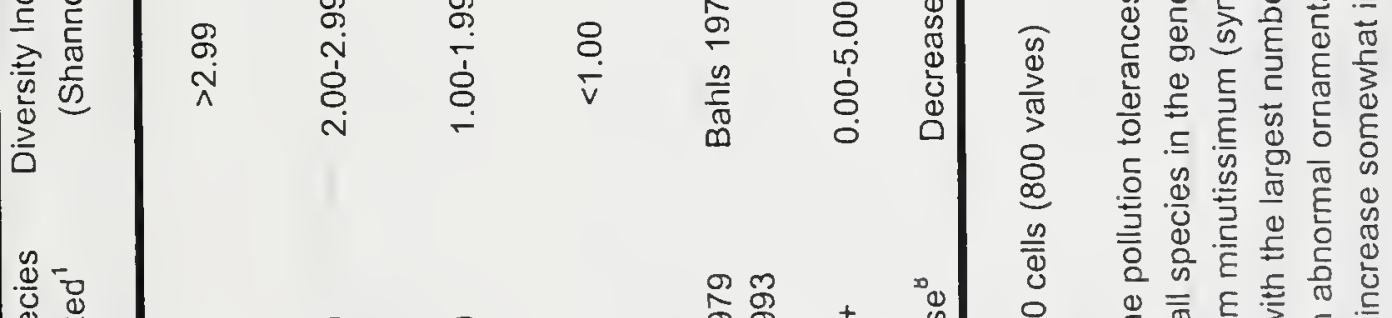

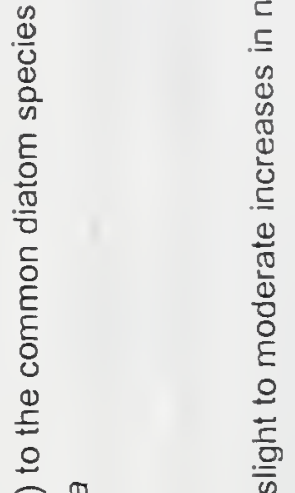

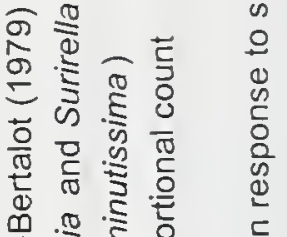

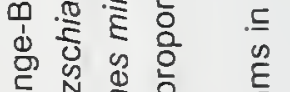

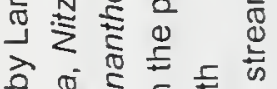

$$
\begin{aligned}
& \text { क }
\end{aligned}
$$

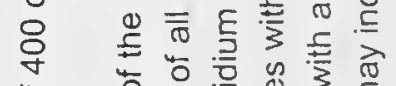

$$
\begin{aligned}
& \text { 하을 }
\end{aligned}
$$

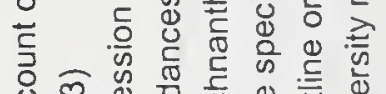

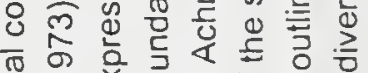

$$
\begin{aligned}
& \text { 등 - }
\end{aligned}
$$

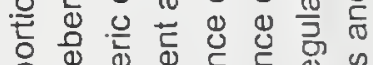

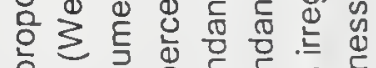

$$
\begin{aligned}
& \text { ه }
\end{aligned}
$$

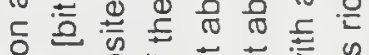

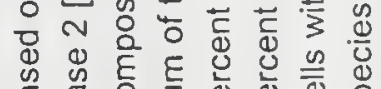

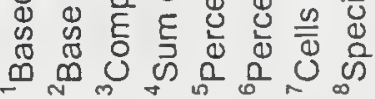




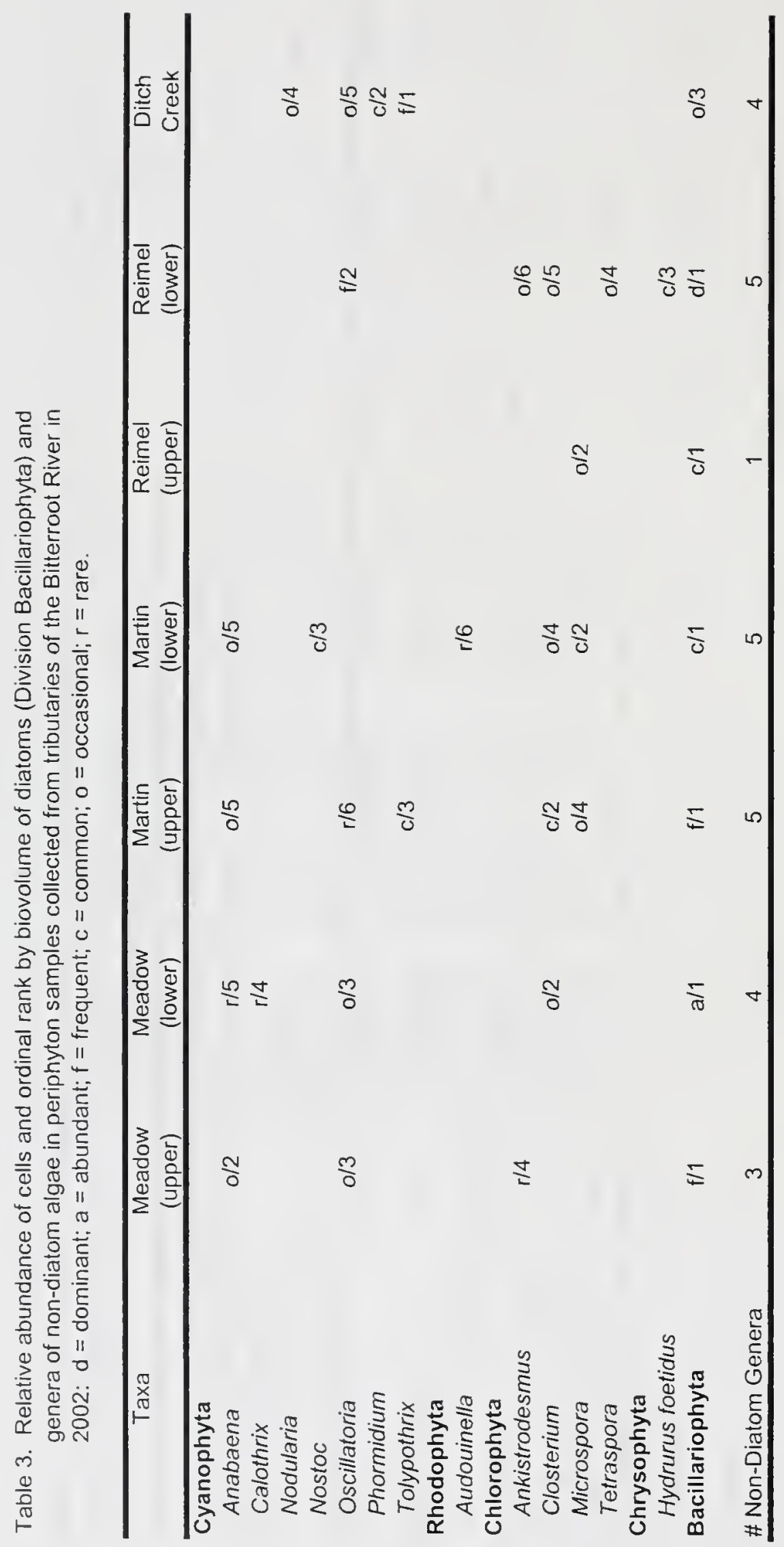




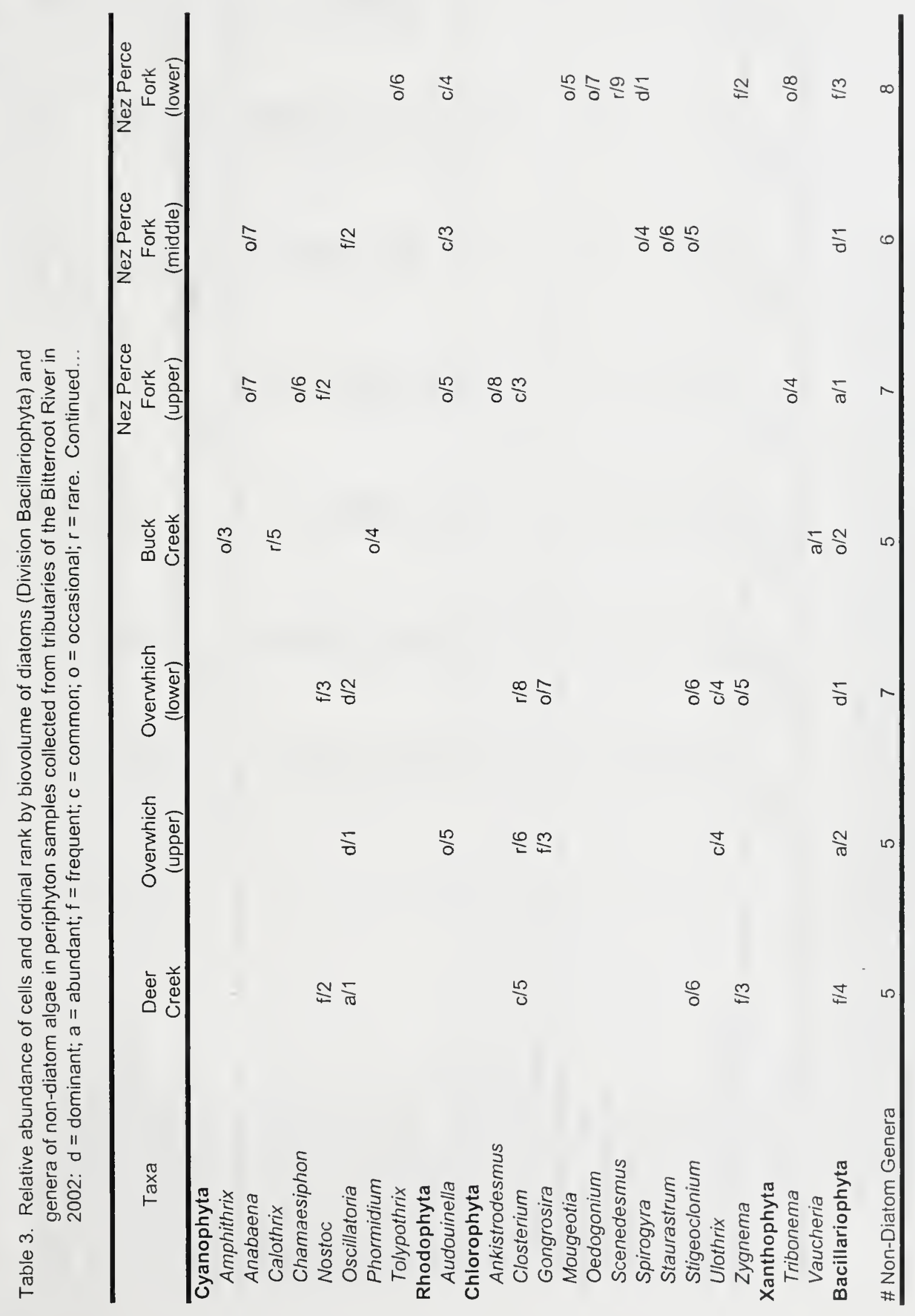




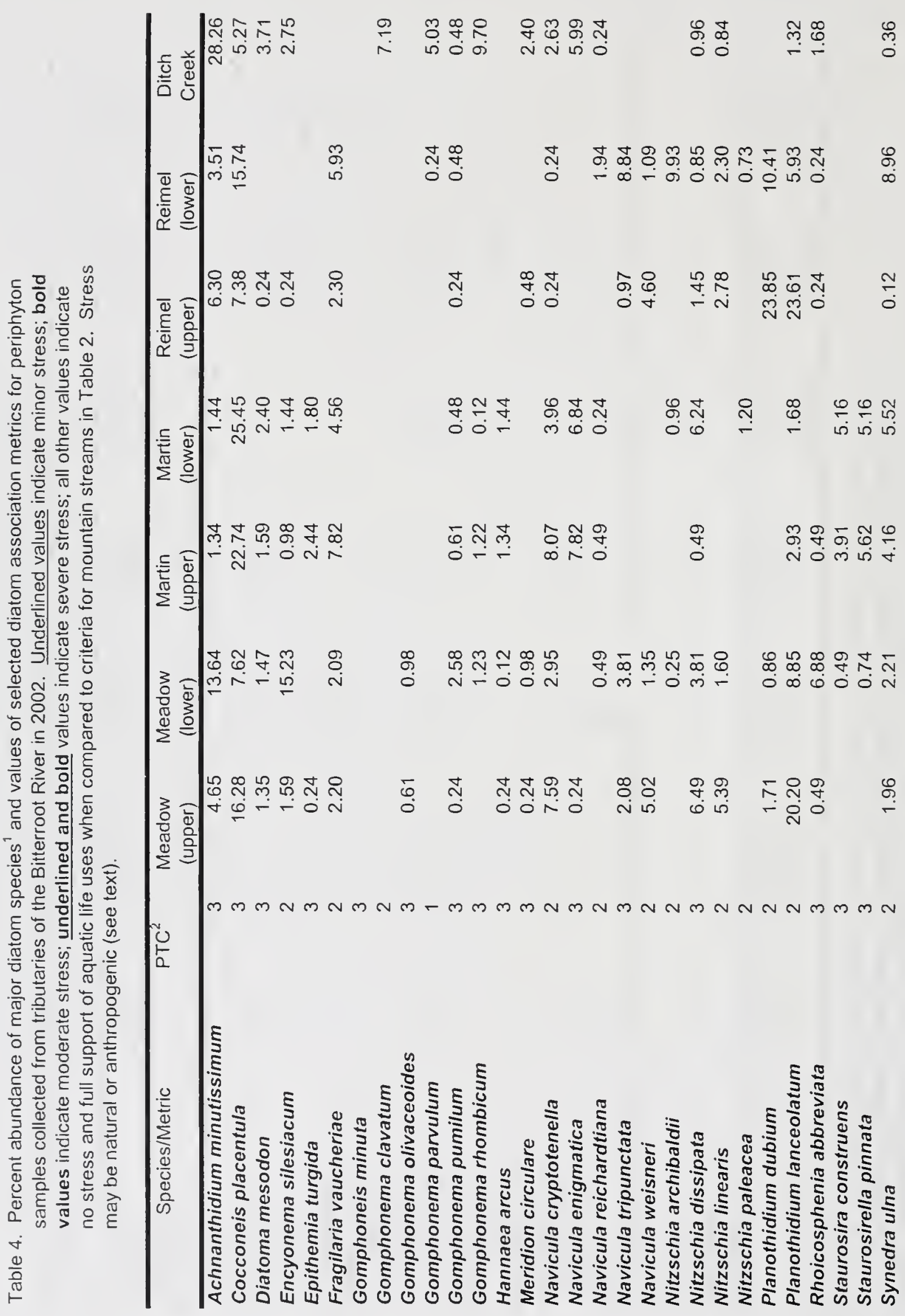


i̊

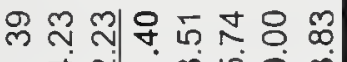

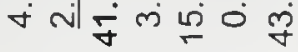

든응 兽

등 is

这造

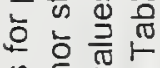

象.돈도

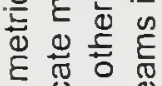

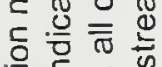

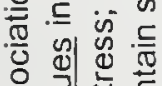

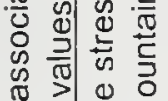

ह 일

은 焉

苧

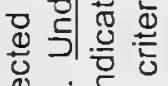

สิ่

还

ㄷำ产

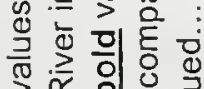

$>$ 和 응

등은 든

ฯ 咆

능

造 흔

के

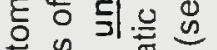

त्ञ की

을 壳范

른은ㅎㅇㅇㅇㅇ

틍 융 윽

ญ.

苋 导

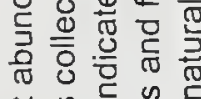

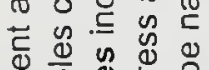

ญ⿺辶寸

돟

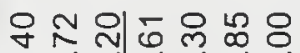

ल vं कं

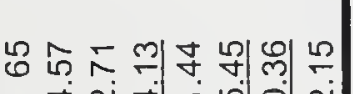

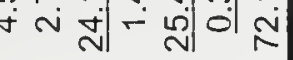

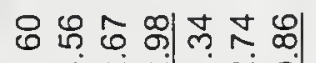

* $\sim$ N

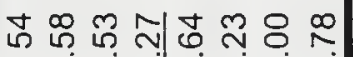

ব

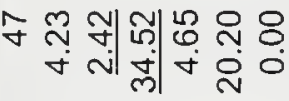




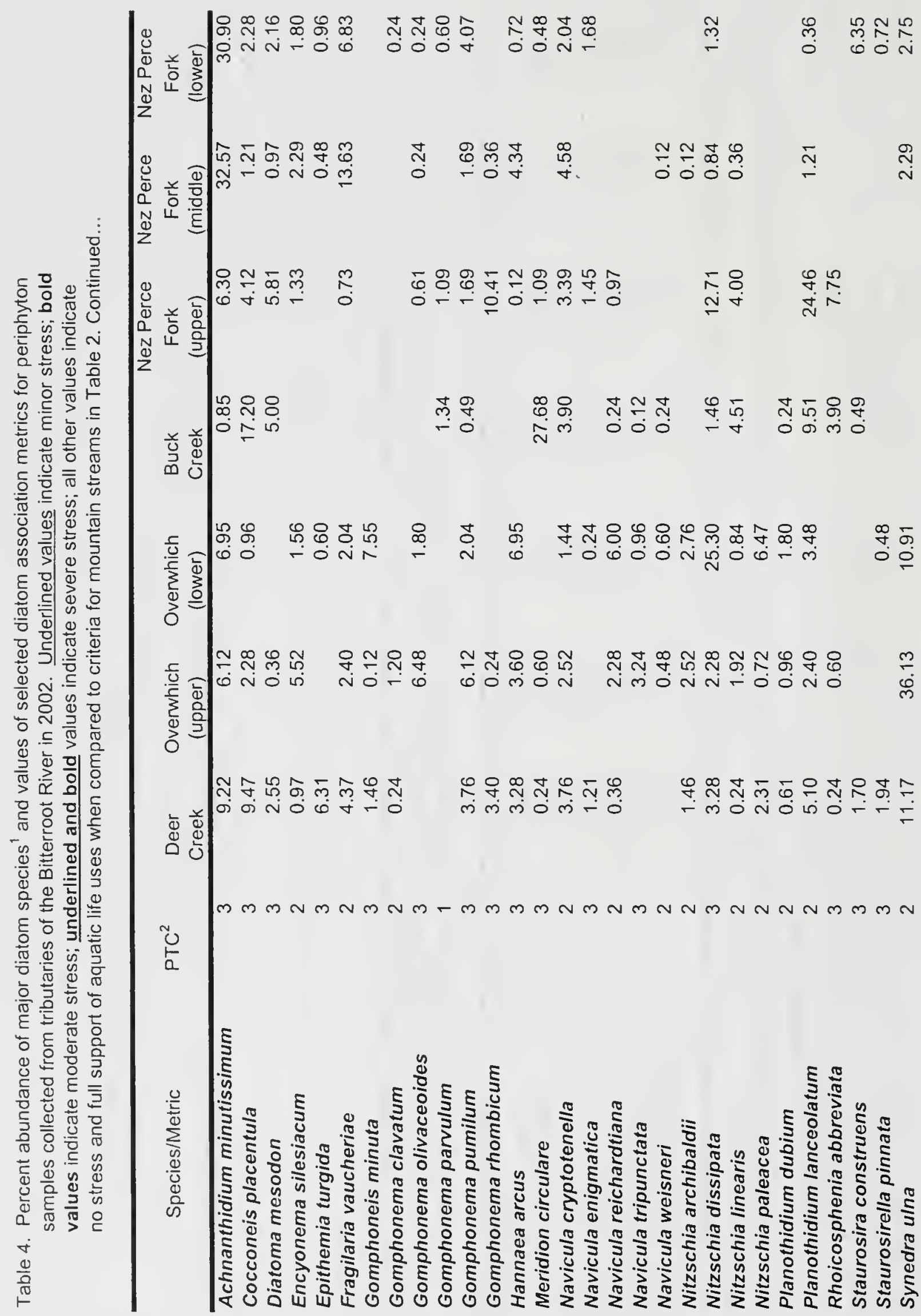




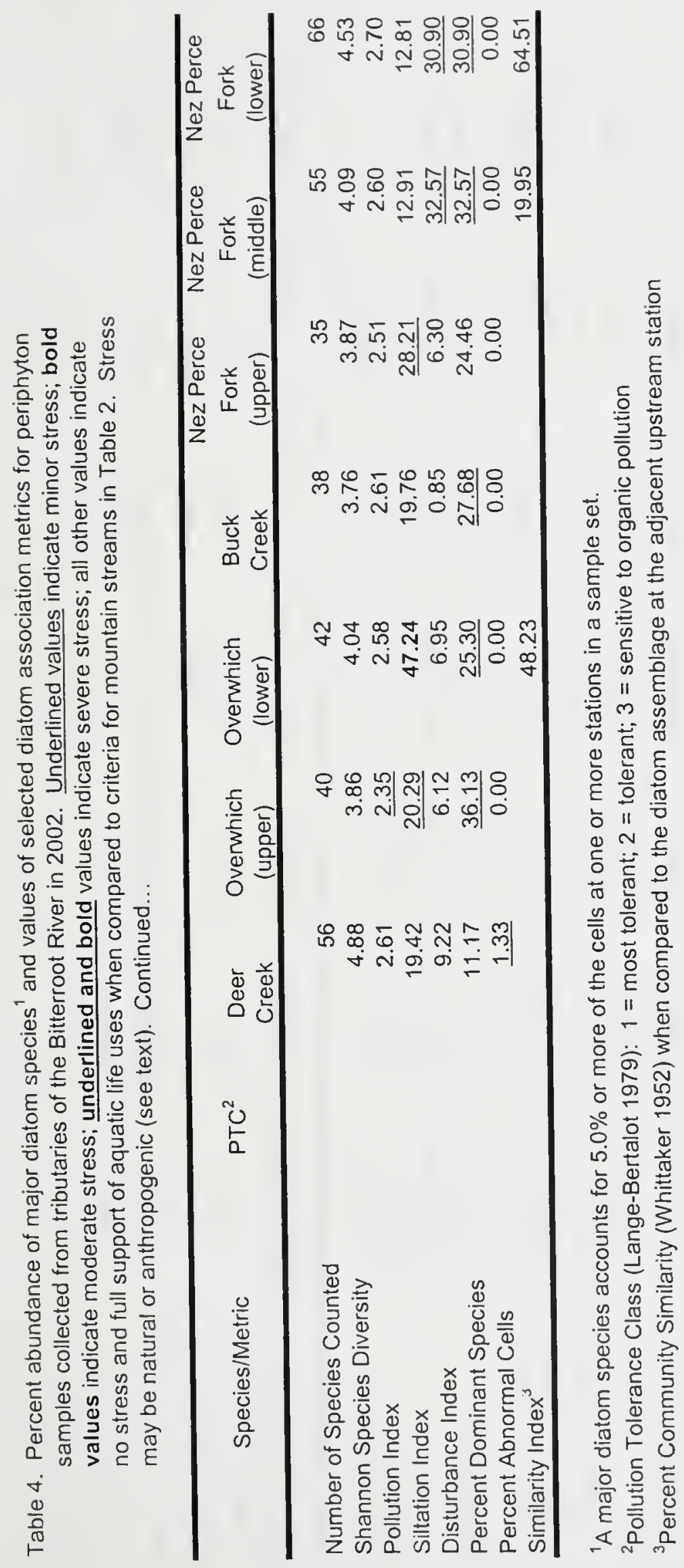




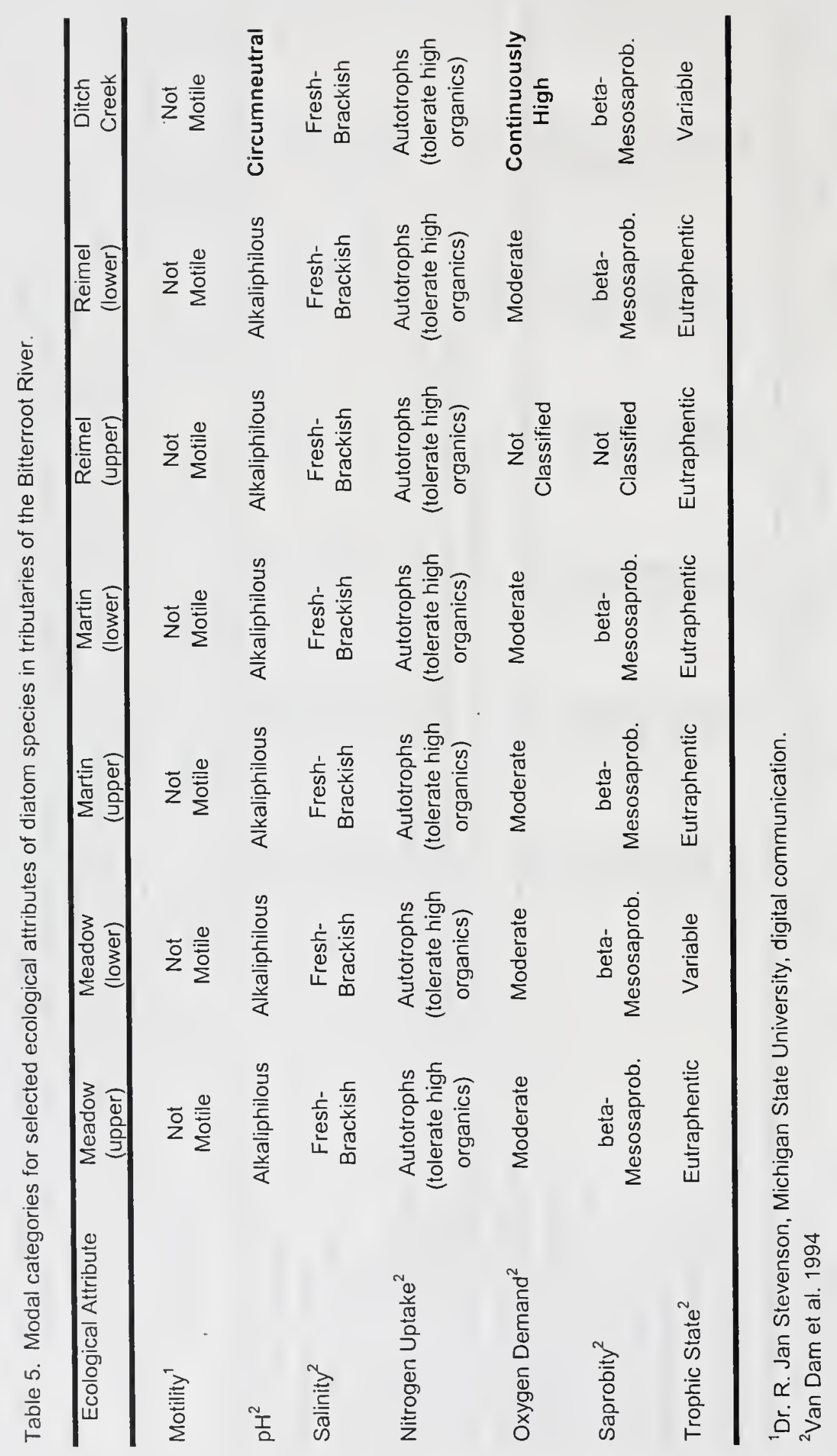




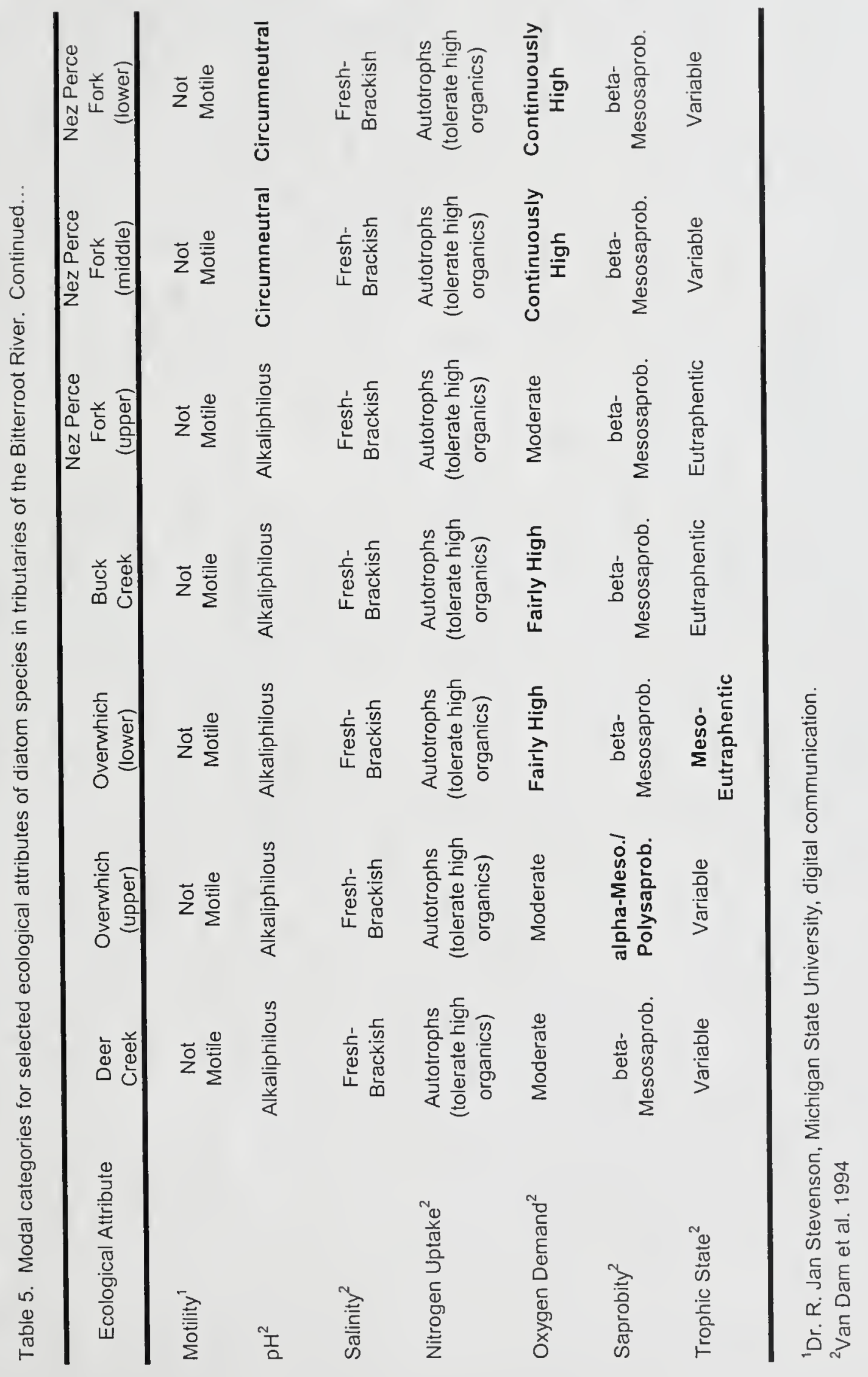


